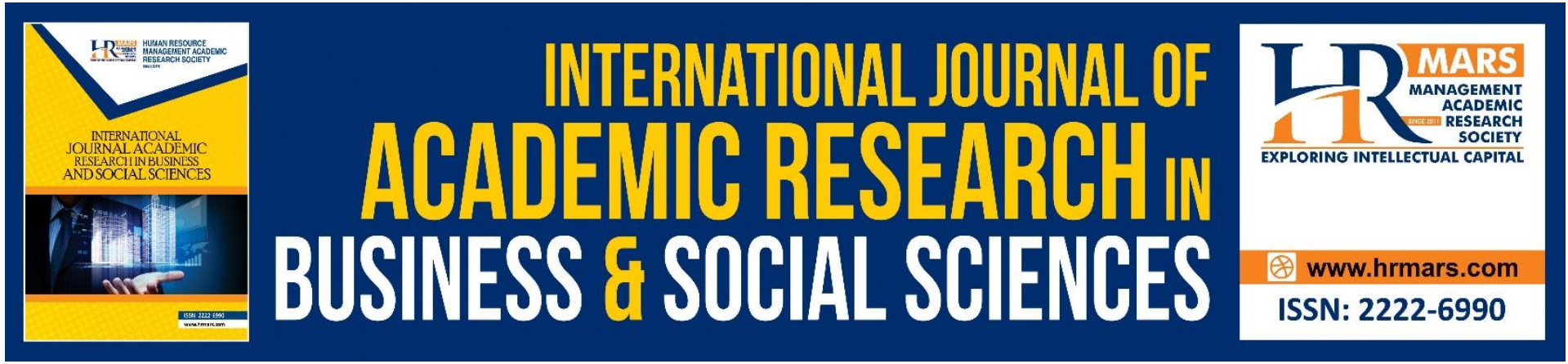

\title{
Factors Influencing the Behavioural Intention on Mobile Shopping Use among Hijab Fashion Consumers in Malaysia: A Conceptual Paper
}

Farrah Nadia Baharuddin, Aini Hayati Musa, Alia Nadira Rosle, Siti Sara Ibrahim

To Link this Article: http://dx.doi.org/10.6007/IJARBSS/v11-i8/10721

DOI:10.6007/IJARBSS/v11-i8/10721

Received: 10 June 2021, Revised: 11 July 2021, Accepted: 30 July 2021

Published Online: 09 August 2021

In-Text Citation: (Baharuddin et al., 2021)

To Cite this Article: Baharuddin, F. N., Musa, A. H., Rosle, A. N., \& Ibrahim, S. S. (2021). Factors Influencing the Behavioural Intention on Mobile Shopping Use among Hijab Fashion Consumers in Malaysia: A Conceptual Paper. International Journal of Academic Research in Business and Social Sciences, 11(8), 201-209.

Copyright: @ 2021 The Author(s)

Published by Human Resource Management Academic Research Society (www.hrmars.com)

This article is published under the Creative Commons Attribution (CC BY 4.0) license. Anyone may reproduce, distribute, translate and create derivative works of this article (for both commercial and non-commercial purposes), subject to full attribution to the original publication and authors. The full terms of this license may be seen at: http://creativecommons.org/licences/by/4.0/legalcode

Vol. 11, No. 8, 2021, Pg. 201 - 209

Full Terms \& Conditions of access and use can be found at http://hrmars.com/index.php/pages/detail/publication-ethics 


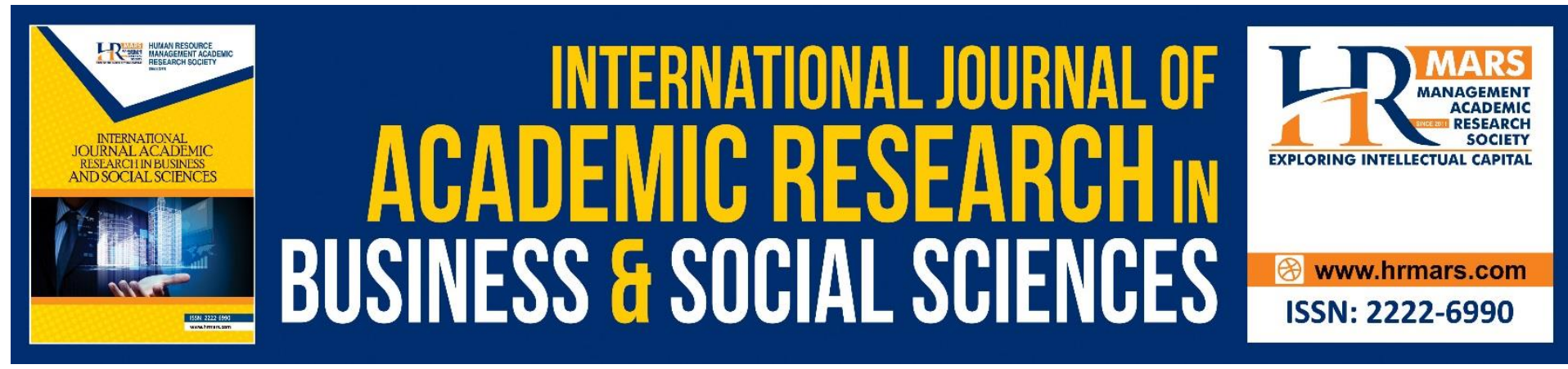

\title{
Factors Influencing the Behavioural Intention on Mobile Shopping Use among Hijab Fashion Consumers in Malaysia: A Conceptual Paper
}

\author{
${ }^{1}$ Farrah Nadia Baharuddin, ${ }^{1}$ Aini Hayati Musa, ${ }^{2}$ Alia Nadira \\ Rosle, ${ }^{1}$ Siti Sara Ibrahim \\ ${ }^{1}$ Faculty of Business and Management, Universiti Teknologi MARA (UiTM), Malaysia, ${ }^{2}$ Faculty \\ of Computer Science and Mathematics, Universiti Teknologi MARA (UiTM), Malaysia.
}

\begin{abstract}
The concept of behavioural intention is one of interesting topics in marketing research. It becomes a crucial factor for companies to understand the underlying factors that create behavioural intention to purchase to stay relevance in the competitive market. However, with the revolution of technology that made mobile shopping become easier, thus, it limits the effort of consumers to visit brick and mortar store. The popularity of using mobile as shopping devices and the shopping activities can be conducted in anytime as well as anywhere and the mobile shopping is being used beyond expectations. Based on this reason, it is vital for marketers to identify the factors that influenced of behavioural intention on mobile shopping use of hijab fashion among Muslim women in Malaysia. Thus, the study investigates the factors influencing behavioural intention on mobile shopping use from the aspect of customer innovativeness, perceived usefulness, perceived ease of use as well as perceived enjoyment. This paper serves an understanding on behavioural intention of hijab fashion consumers using the mobile shopping and provides as a fruitful insight to marketers to segment of the market. Lastly, the study provides a conceptual framework as a preliminary attempt which related to factors influencing behavioural intention on mobile shopping use among hijab fashion consumers in Malaysia.
\end{abstract}

Keywords: Behavioural Intention, Customer Innovativeness, TAM, Hijab Fashion.

\section{Introduction}

In the past of two decades, the outlook of business channel has shift due to the growth of the internet as well as the expansion of mobile technologies (Omar et al., 2021). The new era of technology had tremendously changed the landscape of consumers' lifestyles as well as on businesses performance. The availability of the 24-hour retailing through mobile phones has made an evolution towards the methods of products and services are being offered and purchased. Moreover, mobile technology has become crucial and impacted most of human life. Hence, the consumption of mobile devices for the purpose of mobile shopping has increasing its popularity and the mobile shopping is being used beyond expectation since it can be used in anytime and anywhere (Kim et al., 2015). 
Numerous of mobile devices, namely, tablets as well as smartphones has creating and attract the new form of mobile shopping. Furthermore, mobile commerce in the mobile devices perform to connect between consumers and businesses (Huang et al., 2015). Due to this reason, the concept of mobile shopping to be conducted anywhere and anytime comes into sight as a new opportunity for increasing revenue for companies (Meola, 2021). As such, consumers' buying opportunities have increased by the accessibility to product and services and increased the ease to make purchases. Furthermore, the advancement of technologies benefited for both consumers as well as businesses by having mobile apps, self-checkouts, smart shelf technology and scan-and-go technologies (Inman \& Nikolova, 2017).

Although mobile shopping has been studied on various product brands, limited research has been done on fashion products (Ko et al., 2009), namely, hijab fashion. Moreover, with the impact from pandemic Covid 19, the opportunity of Muslim women to go to the physical store to select and try the hijab is slim. Thus, there is an opportunity for mobile shopping to be conducted anytime and anywhere for purchase hijab or scarves.

Recently, the Islamic fashion has become one of the main contributors in global Islamic industry (Hassan \& Ara, 2020). The rapid growth in Islamic fashion has reflected on the inclination demands of hijab or scarves in the market to complement Muslim women look on attires. They have incorporated the hijab fashion as a part of Islamic faith and blending the contemporary look in donning their hijab (Hassan \& Ara, 2020). However, the intense competition among Islamic fashion players in Malaysia has led to the main obstacles for the business to maintain relevance in the industry (Zainudin et al., 2018). Therefore, this conceptual research paper serves a fruitful insight on factor influencing behavioural intention on mobile shopping use among hijab fashion consumers. Moreover, there is a room of fashion hijab to be emerged as donning a hijab is always complement on nowadays Muslim women' lifestyle to be fashionable (Aziz \& Ariffin, 2016).

\section{Literature Review}

\section{Hijab Fashion in Malaysia}

Muslim women are identifies from the hijab that they wear in order to show their religion as well as their culture (Khalid \& Akhtar, 2018). Wearing a hijab is an expression of Muslim women identity and spiritual faith but also bring the image of fashionable for them (Puspitasari \& Dolah, 2018). The revolution of hijab has evolved, and it has integrated to fashion concept from a few years ago. Recently, the Islamic fashion has become one of the main contributors in global Islamic industry (Hassan \& Ara, 2020).

The rapid growth in Islamic fashion has reflected on the inclination demands of hijab or scarves in the market to complement Muslim women look on attires. They have incorporated the hijab fashion as a part of Islamic faith and blending the contemporary look in donning their hijab (Hassan \& Ara, 2020). In Malaysia, the demand of hijab fashion is blooming in which to adapt the modern lifestyle of fashionable Muslim women customers (Aziz \& Ariffin, 2016). Muslim women are more likely to purchase hijab that suits to their ideals of womanhood and became fashionable due to changing of Muslim women lifestyles, beauty and grooming as well as awareness on appearance. 


\section{Customer Innovativeness}

Innovativeness is defined as a personality that derives from the indicates on the willingness of an individual to adopt ideas or products that are new based on individual experience (Aldás-Manzano et al., 2009; Citrin et al., 2000). Further, a person who has innovativeness perceives to be an opinion leader or an early adopter in using mobile application as well as devices (Gao et al., 2012). In many of the research, explained that consumers who heavily consumed interactive electronic shopping media is categorised as innovators (Eastlick \& Lotz, 1999). The innovators perceived advantages of innovation towards interactive shopping as compared to traditional shopping channels in which accordance with their lifestyles.

Moreover, internet shopping behaviour is influenced either direct or indirectly by innovativeness through consumers' intentions and attitude (Limayem et al., 2000). In view of the literature reviews, found that involvement with the internet, innovativeness as well as predisposition on buying online is the factors influenced future online intention and continuance on online shopping (Goldsmith, 2000). Hence, innovativeness is the key factor affects consumer behaviour in consume internet shopping (Aldás-Manzano et al., 2009; Citrin et al., 2000) as well as significant influence to use fashion mobile application (Soni et al., 2019).

\section{The Technology Acceptence Model (TAM)}

The previous studies shown that TAM is one of the main theories that applied to explain the factors influencing of mobile commerce shopping intention in (Barry \& Jan, 2018; Davis, 1989). The study has proposed the following attributes as follows: -

\section{Perceived Usefulness}

According to Davis (1989), perceived usefulness is defined as the degree on how a person believes that by adopting a system will increase his or her job or task performance. In adopting mobile commerce, an individual believes his or job performance is enhanced by engaging in the online transaction. In many of the research, explained that there is a significant relationship between perceived usefulness and behavioural intention in order to use information system (Agarwal \& Karahanna, 2000; Barry \& Jan, 2018; Lee et al., 2005; Phua et al., 2012). Further, the previous studies also revealed that perceived usefulness has a significant relationship to intention that lead to use of m-commerce (Kasuma et al., 2020).

\section{Perceived Ease of Use}

Perceived ease of use is one of the attributes that have a positive significant towards technology use (Davis, 1989). It defines as a degree in which a person believes that he or she has a freedom by his or her effort in using a technology. Consumers are willing to connect with a technology if it is easy to use as well as very useful. Many of previous research, explained that perceived ease of use has a positive significant on behavioural intention and lead to the use of an information system (Phua et al., 2012). Further, previous studies also revealed that perceived ease of use and intention to lead $\mathrm{m}$-commerce use are significantly correlated (Kasuma et al., 2020). The previous studies mentioned that perceived ease of use is the key factor influencing behavioural intention and has a significant relationship on it (Lee et al., 2005). 


\section{Perceived Enjoyment}

Perceived enjoyment is defined as the degree on how a person believes that in adopting a specific system, namely, m-commerce would be achieving pleasant on its own (Davis, 1989). Thus, perceived enjoyment is an intrinsic motivation that influence a person to adopt a system, whereby, perceived usefulness is viewed as an extrinsic motivation (Agrebi \& Jallais, 2015). The previous studies revealed that perceived enjoyment is a feeling of enjoyment as well as pleasure in which resulted from using a smartphone while shopping serves as a driving force (Agarwal \& Karahanna, 2000). Further, in the context of perceived enjoyment, mentioned that is has a positive influence on behavioural intention (Barry \& Jan, 2018; Lee et al., 2005).

\section{Behavioural Intention on Mobile Shopping Use}

In the context of mobile shopping, behavioural intention is defined on the tendency of consumer to engage on mobile device for the purpose of online purchasing or activities (Barry \& Jan, 2018). The development of online shopping made online shopping become easier at consumers comfort and by limit the effort to visit a physical retail store. Nevertheless, there is a limitation of e-commerce stores functionality, thus, many companies including fashion products companies launched mobile commerce apps for the purpose of mobile shopping (Magrath \& Mccormick, 2013). It was noted that the retail industry believed the mobile technology has potential to serve as a platform to connect to customers and act as a medium to convert sales without visiting to the store (Groß, 2015). Due to this reason, many retail fashions companies have started to invest in creating their own mobile shopping apps. Thus, mobile shopping has revolutionized the conventional shopping experience of customers in visiting a physical store and transform to browse for an options on a mobile shopping apps and pay the products they purchased by using the same application (Groß, 2015; Hung et al., 2012; Kim et al., 2015).

The previous studies shown that consumer innovativeness is the key factor that influenced purchasing of a new product as well as adaptation to innovation (Agarwal \& Prasad, 1998; Hirunyawipada \& Paswan, 2006), encouraging of using internet (Lam et al., 2008), exhibit attitudes on mobile marketing (Gao et al., 2012) and effect on continuation of intention on mobile commerce (June, 2014).

Further, in the context of TAM model towards the behavioural intention, the perceived usefulness has a significance relationship on the behavioural intention (Barry \& Jan, 2018; Ko et al., 2009; Phua et al., 2012). It is also shown that perceived ease of use has a significance positive toward behavioural intention (Lee et al., 2005; Phua et al., 2012). It was noted that, the perceived enjoyment is the key factor influencing behavioural intention (Agrebi \& Jallais, 2015; Barry \& Jan, 2018; Lee et al., 2005; Phua et al., 2012)Moreover, mobile commerce use is being influenced by the behavioural intention and has a significant positive toward mobile commerce use (Barry \& Jan, 2018; Chopdar \& Sivakumar, 2019; Davis, 1989; Faqih \& Mousa, 2015).

\section{Methodology}

The paper is attempted to study on the factors influence behavioural intention toward mobile shopping use among hijab fashion consumers in Malaysia. The proposed independent 
variables are customer innovativeness, perceived usefulness, perceived ease of use and perceived enjoyment. Behavioural intention is the dependent variable for this study.

The study will use descriptive research for the purpose to better gain fruitful insight and to explain the relationship of customer innovativeness, perceived usefulness, perceived ease of use, perceived enjoyment that influence behavioural intention on mobile shopping use among hijab fashion consumers. The structured questionnaire will be given to respondents in regard to assess their behavioural intention on mobile shopping use. Moreover, several statistical tools will be adapted for the study, namely, descriptive analysis, correlation as well as multiple regression. Thus, the proposed conceptual framework are as follows: -

Figure 1: The conceptual framework of the study

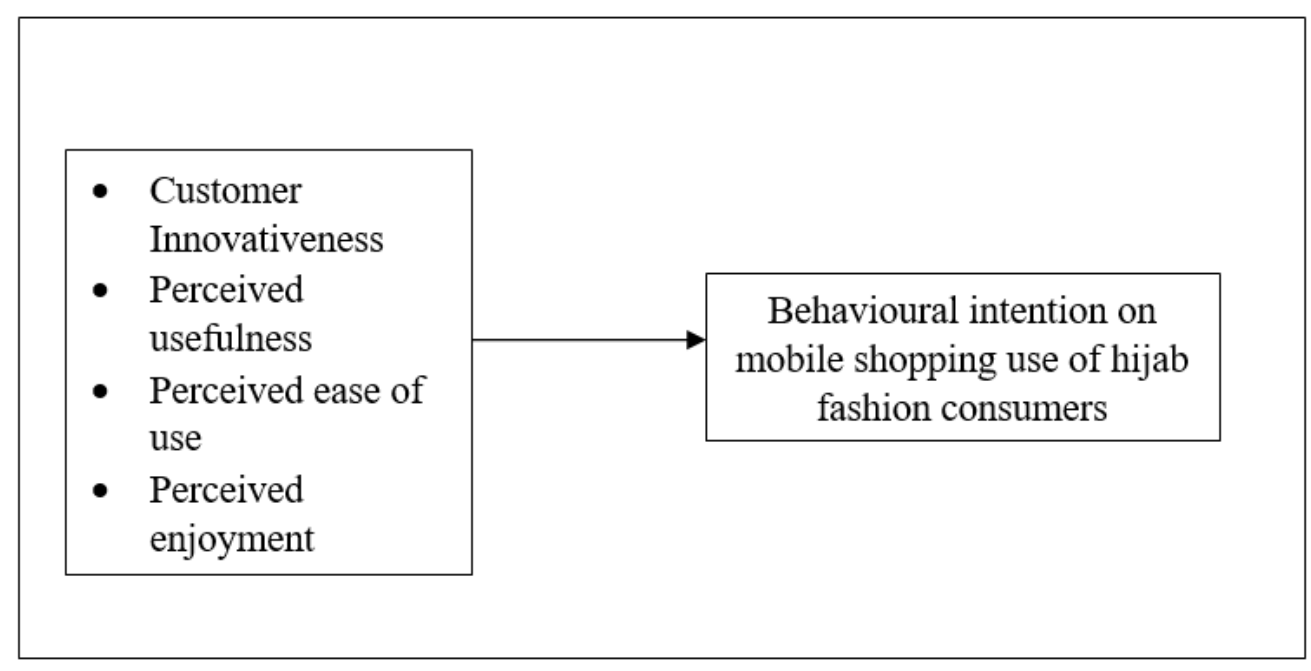

\section{Conclusion}

In this paper, the study is proposed to conceptually assess the factor influencing behavioural intention on mobile shopping use among hijab fashion consumers in Malaysia. Customer innovativeness, perceived usefulness, perceived ease of use and perceived enjoyment are the proposed variables in creating behavioural intention on mobile shopping use among hijab fashion consumers. It is hoped that the proposed framework will contribute for scholars, hijab fashion companies as well as marketers in providing fruitful insight. Thus, it is recommended for future researchers to do an empirical study on the proposed framework.

\section{Acknowledgement}

All authors are equally contributed to the conceptual as well as the design of the study.

\section{Corresponding Author}

Farrah Nadia Baharuddin

Senior Lecturer Faculty of Business and Management, Universiti Teknologi MARA, Negeri Sembilan Branch, 71300 Rembau, Negeri Sembilan, Malaysia.

Email: farrahnadia@uitm.edu.my

\section{References}

Agarwal, R., \& Karahanna, E. (2000). Time Flies When You're Having Fun: Cognitive Absorption and Beliefs about Information Technology Usage. MIS Quarterly, 24(4), 665-694. 
Agarwal, R., \& Prasad, J. (1998). A Conceptual and Operational Definition of Personal Innovativeness in the Domain of Information Technology. Information Systems Research, 9(2), 204-215.

Agrebi, S., \& Jallais, J. (2015). Explain the intention to use smartphones for mobile shopping. Journal of Retailing and Consumer Services, 22, 16-23. https://doi.org/10.1016/j.jretconser.2014.09.003

Aldás-Manzano, J., Ruiz-Mafé, C., \& Sanz-Blas, S. (2009). Exploring individual personality factors as drivers of M-shopping acceptance. Industrial Management \& Data Systems. https://doi.org/10.1108/02635570910968018

Aziz, Z. D. A., \& Ariffin, S. (2016). Factors influencing brand loyalty toward fashion hijabs: A Conceptual Paper. International Academic Research Journal of Business and Technology, 2(2), 194-198.

Barry, M., \& Jan, M. T. (2018). Factors influencing the use of M-commerce: An extended Technology Acceptance Model perspective. International Journal of Economic, Management and Accounting, 26(1), 157-183.

Chopdar, P. K., \& Sivakumar, V. J. (2019). Impulsiveness and its impact on behavioural intention and use of mobile shopping apps: a mediation model. International Journal of Business Innovation and Research, 19(1), 29-56.

Citrin, A. V., Sprott, D. E., \& Silverman, S. N. (2000). Adoption of Internet shopping : the role of consumer innovativeness Adoption of Internet shopping: the role of consumer innovativeness. Industrial Management \& Data Systems, 100(7), 294-300.

Davis, F. (1989). Perceived Usefulness, Perceived Ease of Use, and User Acceptance of Information Technology. MIS Quarterly, 13(3), 319-340. https://doi.org/10.1016/j.cell.2017.08.036

Eastlick, M. A., \& Lotz, S. (1999). Profiling potential adopters and non- adopters of an interactive electronic shopping medium. International Journal of Retail \& Distribution Management, 27(6), 209-223.

Faqih, K. M. S., \& Mousa, M. R. (2015). Journal of Retailing and Consumer Services Assessing the moderating effect of gender differences and individualism-collectivism at individual-level on the adoption of mobile commerce technology: TAM3 perspective. Journal of Retailing and Consumer Services, 22, 37-52.

https://doi.org/10.1016/j.jretconser.2014.09.006

Gao, T., Rohm, A. J., Sultan, F., \& Huang, S. (2012). Antecedents of Consumer Attitudes Toward Mobile Marketing: A Comparative Study of Youth Markets in the United States and China. Thunderbird International Business Review, 54(2), 211-224. https://doi.org/10.1002/tie

Goldsmith, R. E. (2000). Identifying Wine Innovators: A Test of the Domain Specific Innovativeness Scale Using Known Groups. International Journal of Wine Marketing, 12(2), 37-46.

Groß, M. (2015). Mobile shopping: a classification framework and literature review. International Journal of Retail \& Distribution Management, 43(3), 221-241. https://doi.org/10.1108/IJRDM-06-2013-0119

Hassan, S. H., \& Ara, H. (2020). Hijab Fashion Consciousness Among Young Muslim Women In Malaysia. 07(08), 446-467.

Hirunyawipada, T., \& Paswan, A. K. (2006). Consumer innovativeness and perceived risk: implications for high technology product adoption. Journal of Consumer Marketing, 23(4), 182-198. https://doi.org/10.1108/07363760610674310 
Huang, E. Y., Lin, S., \& Fan, Y. (2015). Electronic Commerce Research and Applications M-SQUAL: Mobile service quality measurement. Electronic Commerce Research and Applications, 14(2), 126-142. https://doi.org/10.1016/j.elerap.2015.01.003

Hung, N.-C., Yang, S.-T., \& Hsieh, T.-C. (2012). AN EXAMINATION OF THE DETERMINANTS OF MOBILE SHOPPING CONTINUANCE. International Journal of Electronic Business Management. https://doi.org/10.1086/227766

Inman, J. J., \& Nikolova, H. (2017). Shopper-Facing Retail Technology: A Retailer Adoption Decision Framework Shopper-Facing Retail Technology: A Retailer Adoption Decision Framework Incorporating Shopper Attitudes and Privacy Concerns. Journal of Retailing, 93(1), 7-28. https://doi.org/10.1016/j.jretai.2016.12.006

June, L. (2014). Are personal innovativeness and social influence critical to continue with mobile commerce? Internet Research, 24(2), 134-159. https://doi.org/10.1108/IntR05-2012-0100

Kasuma, J., Liyana, F., Sulaiman, A., \& Sarpinah, B. (2020). Attitude, Perceived Usefulness and Perceived Ease of Use towards Intention to Use M-Commerce: A Case of Grocery Shoppers in Kuching, Sarawak. Journal of Entrepreneurship and Business, 8(71-84). https://doi.org/10.17687/JEB.0801.

Khalid, K., \& Akhtar, S. (2018). Factors influencing fashion consciousness in hijab fashion consumption. Journal of Marketing and Logistic, 1, 88-103. https://doi.org/10.1108/JIMA-10-2014-0064

Kim, C., Li, W., \& Kim, D. J. (2015). An Empirical Analysis of Factors Influencing M-Shopping Use. 2012, 974-994. https://doi.org/10.1080/10447318.2015.1085717

Ko, E., Kim, E. Y., \& Lee, E. K. (2009). Modeling consumer adoption of mobile shopping for fashion products in Korea. Psychology and Marketing. https://doi.org/10.1002/mar.20294

Lam, S. Y., Chiang, J., \& Parasuraman, A. (2008). The effects of the dimensions of technology readiness on technology acceptance: An empirical analysis. Journal of Interactive Marketing, 22(4), 19-39. https://doi.org/10.1002/dir

Lee, M. K. O., Cheung, C. M. K., \& Chen, Z. (2005). Acceptance of Internet-based learning medium: the role of extrinsic and intrinsic motivation. Information and Management, 42, 1095-1104. https://doi.org/10.1016/j.im.2003.10.007

Limayem, M., Khalifa, M., \& Frini, A. (2000). What Makes Consumers Buy from Internet ? A Longitudinal Study of Online Shopping. IEEE TRANSACTIONS ON SYSTEMS, MAN, AND CYBERNETICS, 30(4), 421-432.

Magrath, V., \& Mccormick, H. (2013). Marketing design elements of mobile fashion retail apps. Journal of Fashion Marketing and Management: An International Journal, 17(1), 115-134. https://doi.org/10.1108/13612021311305173

Meola, A. (2021). Rise of M-Commerce : Mobile Ecommerce Shopping Stats \& Trends in 2021 Mobile Ecommerce Benefits. Https://Www.Businessinsider.Com/Mobile-CommerceShopping-Trends-Stats.https://www.businessinsider.com/mobile-commerceshopping-trends-stats

Omar, S., Mohsen, K., Tsimonis, G., Oozeerally, A., \& Hsu, J. (2021). M-commerce : The nexus between mobile shopping service quality and loyalty. Journal of Retailing and Consumer Services, 60(April 2020), 102468. https://doi.org/10.1016/j.jretconser.2021.102468

Phua, P. L., Wong, S. L., \& Abu, R. (2012). Factors influencing the behavioural intention to use the internet as a teaching-learning tool in home economics. Procedia - Social and Behavioral Sciences, 59, 180-187. https://doi.org/10.1016/j.sbspro.2012.09.263 
Puspitasari, C., \& Dolah, J. (2018). The analysis of integration between hijab concept and fashion in Indonesia. 3rd International Conference on Creative Media, Design and Technology, 207, 325-328.

Soni, M., Jain, K., \& Kumar, B. (2019). Factors affecting the adoption of fashion mobile shopping applications. Journal of Global Fashion Marketing, 00(00), 1-19. https://doi.org/10.1080/20932685.2019.1649165

Zainudin, M. I. Bin, Ali, A.-A. E. B. R., Syahmi, A., Fadzil, A., Sarin, M. F., Zaki, N. A. S. B. A., Othman, A. K., \& Hassan, F. H. (2018). Halal Brand Personality and Brand Loyalty among Millenials Modest Fashion Consumers in Malaysia: A Conceptual Paper. International Journal of Asian Social Science, 8(11), 985-994.

https://doi.org/10.18488/journal.1.2018.811.985.994 